ISBN 978-93-86878-06-9

8th International Conference on Literature, Languages, Humanities and Interdisciplinary Studies

(LLHIS-17)

Kuala Lumpur (Malaysia) Dec. 14-15, 2017

\title{
Educative Game as a Strategy Increasing Quality of Children Age School
}

\author{
Riska Ainun Wulandari Zalukhu \\ Department of Family and Consumer Science, Faculty of Human Ecology, Bogor Agricultural University \\ Campus IPB Dramaga Bogor, West Java, Indonesia (e-mail: riskazalukhu96@gmail.com)
}

\begin{abstract}
School-aged children are periods that are undergoing a period of growth and development. Parents and others should be good motivators of child growth and development. The game is a self-chosen activity without any element of coercion, pressure, and without being urged by a full sense of responsibility. The game has no further specific purpose. The goal of the game lies in the game it self and is accomplished at play time. Playing is not the same as working. Working has a further goal to do over and over again and not to waste a lot of wasted time, the goal is achieved once the job is done. Children prefer play activities because within them there is an inner urge and self-evolving drive. On the other hand, children just assume that the game just for fun only. This is because the process of doing something is more appealing to the children than the results it gets. Children and games are two notions that are almost inseparable from one another. Both have strong interdependencies and interconnections for the social life of the child. Thinking about a child always raises an association about play, where it plays the quality of the child's character towards the social group playing. Children's special needs in the neighborhood are playing. Types of games for children need to be considered well. A game suitable for children is an educative game. Many games teach people to preserve the environment, minimize environmental damage, and take care of the child's environment as a whole aiming to change human behavior towards the environment including in school-aged children. Playing activities and procedures can serve as a tool or medium to introduce children about the world of the environment, shape aspects of child development, and how to become an environmentally friendly person. Children prefer a more active game to perform various activities performed before and after each day. In addition, the game can shape aspects of child development ranging from fine motor skills and abusive, passive and active child communication, cognitive development, social skills, independence, emotion, and action as the game progresses. The principle in the game requires honesty and liveliness of children. Thus playing is not a waste of time because during the actual play the child also performs the learning process. So we need to realize the world of children is a world of play and children develop with play activities. Therefore, we should not take the time to play from their lives.
\end{abstract}

Keywords: school age child, educative game, child development aspect, child character

\section{Introduction}

In some countries there are many cases that occur at the lower school level. The most common cases are student fights, bullying, extortion, and other cases that damage the moral of the child. The prevalence of bullying in schools occurring in some Asian, American, and European countries is approximately (8\% -50\%). The number of bullying cases is half of the other cases (Soedjatmiko et al. 2011). In addition, other cases state that 11.3 percent to 49.8 percent of bullying occur in primary schools. In primary schools have a vulnerable strong enough to carry out cases of bullying (Dake et al. 2003). According to KPAI data (2014), pending from 2011 to August 2014, there are 369 about 75 percent of complaints related to the problem here another 25 percent are in the education field.

Bullying is characterized as an aggressive behavior that has a high impact on a child's destructive development with deliberate elements and repeated actions with the aim of harming, marginalizing and harming 
his victims and may be accompanied by differences in each other or power imbalances between the offender and victims (Latifah and Fika 2012). This negative behavior is particularly strong in children where the behavior may be physical contact, verbal contact, facial or sexual gestures, deliberate exclusion from individuals and groups or through electronic devices or cyberbullying and other social media (Dake et al. 2003; Siswati and Widayanti 2009). Bullying that occurs in schools has not received serious attention from teachers or parents maximally. Statistical results from School Bullying Statistic, found that 85 percent of cases of bullying are not stopped by educators. This indicates that the bullying case exceeds half of it does not receive upgrading from educators (Andina and Elga 2014). The results have also shown that bullying behavior that is not resolved quickly in schools can cause negative effects for children especially those that occur in primary school-aged children, which later can affect the development of children at higher school levels. There is a significant correlation between the behavior of bullying and the health of the child causing various mental disorders of the child either physically, psychologically or socially (Dake et al. 2003).

School age (6-12 years) is a time when there are various changes in the growth and development of children that will affect the formation of characteristics and personality of children starting from early to adulthood. Childhood life is a very powerful and important life changing period within a child. The stage of child development is divided into eight stages in the life span of a child (Hurlock 1980). At the age of 6-12 years, the child is at the stage of industry development (sense of ability) vs. inferiority (low self-esteem). Both of these phases have changed the lives of children in building the child's self-personality. If the child is not able to develop himself according to the stages of child development, both academic and non academic then that will develop against the child is a feeling of inferiority. Feelings of inferiority will affect the child's identity (Nurrohmaningtiyas 2008). The nature of good emotional intelligence plays an important role in fostering a sense of ability and accustomed in the child. Failure at some stage will affect the next stages and will impact on the limited ability of children to explore. The child will be difficult to instill good personality so that the child needs to be given direction when out of the family group to a wider group such as school and community environment, in hopes of achieving development appropriate to his age group through skills improvement, knowledge base, and environmental extension to train the child's self-personality for the better (Potter and Perry 2005). School environment can expand the child's world and become a place of development of stressor that can interfere with child development especially child mental health such as violence among student or bullying which always rampant happened at child environment.

The game is a self-chosen activity without any element of coercion, pressure, and without being urged by a full sense of responsibility. Educational games will help children achieve aspects of child development well. The game has no further specific purpose. The goal of the game lies in the game itself and is accomplished at play time. Playing is not the same as working. Working has a further goal to do over and over again and not to waste a lot of wasted time, the goal is achieved once the job is done. Children prefer play activities because within them there is an inner urge and self-evolving drive. On the other hand, children just assume that the game just for fun only. The game is also one of the dominant forms of social activity in the early days of children. Children's activities spend more time outdoors to play with friends than with other activities. Play activities are done for fun and achieve aspects of child development well. Aspects of child development from the cognitive stage (moral knowledge, moral feelings, and moral actions) to the stage of child independence. This is because the process of doing something is more appealing to the children than the results it gets. Children and games are two notions that are almost inseparable from one another. Both have strong interdependencies and connections for the child's social life. Thinking about a child always raises an association about play, where it plays the quality of the child's character towards the social group playing. Children's special needs in the neighborhood are playing (F.J. Monks et al., 1989).

The moral value of parents should be given to the child, with the aim of the child can be the character and inner character used in dealing with situations or circumstances in a moral way. Moral in children must be implanted from an early age, so that the development of children can shape the quality of children's character 
(Lickona 2013). Moral values will form a quality character, which is used as an important foundation in the formation of civilized and prosperous society. A civilized and prosperous society is a human who has a quality character (Megawangi 2009). The child is God's most beautiful gift that is used as the next generation of the nation, so the child should grow and develop well and maturely mature based on the stages of its development. Morally mature children will be able to judge something good or bad in the face of every circumstance, thus avoiding immoral behavior. Children who behave according to morals are children of good character. Lickona (2013) states that a person of character is the one who knows goodness, wants goodness, and does good. This kind of goodness will shape the quality of the child's character well.

Children whose character qualified should grow and develop well, where children are state assets that will be involved in nation building in the future, especially children of primary school age. Primary school-aged children are the process and outcomes of children learning from shared experiences of family and school environments. Therefore, children should get direction, guidance, and mentoring from more mature people, especially parents. Children start spending time with friends and family (Santrock 2012). In this article, the child is expected to form moral knowledge, moral feelings, and good moral actions. Therefore, it is important to do a meta-analysis of the relationship of educational games with the increased quality of school children character.

\subsection{Bronfenbrenner Ecological Theory}

Family is a place for children to be educated and raised well (Megawangi 2009). One of the factors that influence the development of children is the micro environment, especially the family environment and school. The child interacts with the family at home and in the surrounding community. The theory underlying this research is Bronfenbrenner's ecological theory. This ecological theory prioritizes environmental factors, where the influence of environmental systems is very strong on the development of children (Santrock 2012). The division of this system is grouped into five environmental systems, including microsystems, mesosystems, ecosystems, macrosystems, and chronosystems.

The micro-environment is the first place a child lives like a family environment, peers, school, and neighbors. Children always interact face-to-face with parents, teachers, peers, and others. In this environment, most children interact to evolve to form patterns and habits of everyday life. Both mesosystems are the relationship between experience in the family with experience in school, family and peers. All three ecosystems occur when experience is associated with the social environment and the individual has no active role in the individual context itself. The four macroscopes are the culture in which individuals live. Fifth, the chronosystem is an environmental event and a transition from a series of life and socio-historical circumstances (Santrock 2012; Puspitawati and Setioningsih 2012).

\subsection{Kohlberg Moral Development Theory}

Kohlberg (1977) argues that virtually every person is moral, whose development is divided into several stages including the conventional pre consisting of two stages, namely the heteronomist (the child is egocentric so that they assume that his feelings can be understood by others) moral behavior associated with punishment, whatever is valued is a good deed, and whatever is punished is a bad act) and the individual (the child's condition begins to understand that the other person has different needs and perspectives) Behavior is judged good when it can meet the interests of the individual.

The conventional consists of two stages: interpersonal comformity, interpersonal and interpersonal expectations, self-esteem, affection and loyalty are valued and viewed as the basis of moral judgment Moral is good according to the child if they are favored by others) and law and order (moral is said to be good if it is legal (legal and legal) applicable in society Law or rules must be obeyed, even if unfair Law or rules must be obeyed because to maintain social order in society).

Post conventional consists of two stages, namely social contact and individual rights (validity of law must be changed if it can not maintain and protect the basic rights and values of human) and universal ethical principles (individuals develop internal moral code based on universal values and the human rights that precede the rules 
and social laws are confronted with the conflict between law and conscience, the conscience to be followed despite the risks).

\subsection{Aspects of Child Development}

Children in primary school age generally have characteristic behavioral characteristics and are found in that age period. Characteristics of such behavior include the formation of peer groups, dishonest behavior or lying, cheating behavior, fear, and stress. In addition to the above behaviors, the development of school-age behavior also includes coping patterns and switching activities (Potter and Perry 2005).

According Hurlock (1980) defines the characteristics of children at school age as a period of group where the child's attention is on the desire to be accepted by the group. At this stage the child will experience the process of adjusting to the standards set by the group. The main characteristic of primary school-aged children is the formation of peer groups. Where at this age the child will begin to divert his attention from the family to the attention to cooperation among friends in groups. This childhood starts from the age of one year to the age of twenty-one which is divided into three periods namely early childhood (1-6 years), mid (6-12 years), and end (12-21 years).

The middle period in childhood is often referred to as the school period or elementary school period. This school-age period starts with children aged 6-12 years divided into three stages of age ie transition stage or primary stage (6-7 years), mid-stage (7-9 years) and pre-teen (10-12 years) (Potter and Perry 2005). This period is regarded as a latent period in childhood because in this period, everything that happens and gained during this period will continue to the next stage of development.

\subsection{Character of Primary School Children}

Parents should teach the values as the basis for character formation (Lickona 2008). Character is a dialectical motion in a dynamic individual consolidation process so that the result of personality character is stable. The term character is considered the same as the personality that is characteristic, characteristic, or characteristic that is typical of a person who is the formation of the environment it receives (Koesoema 2007).

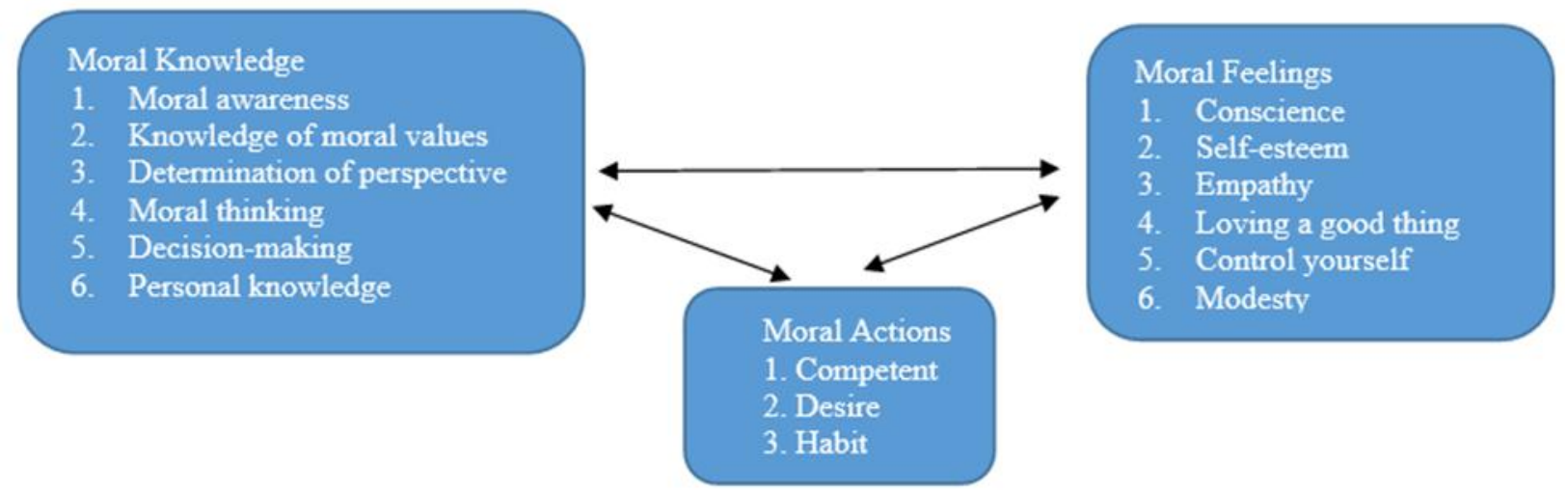

Fig 1. Good Character Component Thomas Lickona (2012)

Lickona (2012) suggests that characters have three parts that are interconnected with one another: moral knowledge, moral feelings, and moral behavior. Good characters are knowing good things, wanting good things, and doing good things. These three things will represent the character we want according to morals.

Humans have a consciousness of life so that with the consciousness it has allows people to live better in behaving. Such behavior leads people to character life. Everyone has a moral awareness and a sense that is formed from the interaction they bring from the beginning with experience with their family. This is to distinguish the degree with others. Morals are able to shape human behavior and make judgments about the behavior of others. Sympathy, Responsibility, and Authority are sentiments about humanity, we feel the pain that is happening. We feel responsible for it. But, we do not feel the pain of others, we feel irresponsible for 
what happened. If we consider sympathy and justice to be important, we sacrifice to help by doing good for the sake of necessity. Sympathy and justice are important, we always do good, despite being hurt (Wilson 1993).

\subsection{Forms of Educational Games For Children}

Keep in mind that play activities do not always require "toys". However, not all toys played by children today have educational or educational elements, where the game is designed specifically for educational purposes. When we observe children playing, play activities can be divided into two types, namely:

a. Play a lot of motion (active)

Multi-motion play has many motion characteristics, such as; run, jump, kick, and others. This method is useful for children in terms of training skills of various things. Most boys love this type of game. By playing actively as if the child is channeling excessive energy. Included in the active play for example is a crank, rubber jump, play ball, etc.

b. Play with little movement (passive)

Playing with a little movement has the character of not using too much exertion, the atmosphere of playing more calm and relaxed. For example playing bekel, board unloading pairs, category cards, see the picture books, reading, listening to music, etc.

Generally girls prefer this type of game. Often the game is accompanied by pretending or fantasizing, such as cooking, playing guests and others. Whether a boy or a girl likes a passive or active type of play depends on the character and personality of the child, and not on the type of her. For boys and girls both types of games are very good or equally good for their development, as long as it is always cultivated so that children always get a chance to explore the environment and both types of games are done in a balanced manner.

Children who like to play actively should be directed also for some time is used to play passively, for example to read books, listening to music or other types of calm games. Conversely, if the child likes to play passively, should be encouraged to play actively, so the development of the muscles of the body and social development or associate with his friends to grow.

\section{Conclusions and Recommendations}

Educative games have a very important role to the development of children. The moral awareness applied in this educational game can support the quality of schoolchildren's character. School-aged children are always vulnerable to a wider environment, one of them micro environments such as family environment and school environment. Basically, the child is always dependent on others to get instruction, instruction, guidance, and mentoring from a more mature person. Parents should also be more active to train the child's personality into a quality character. The character of girls is more than boys. That is, girls aged schoolchildren have a proportion of more characters. Children know and interact directly with nature, peers, and how to maintain the environment well. The principle before play is to have the nature of honesty and liveliness of children in responding to the game. This type of educational children's games will train and shape the child's personality from the aspect of cognitive development (values of qualified characters in the form of moral knowledge, moral feelings, and moral actions) to self-reliance.

Based on the various theories that have been described, children should be given the freedom to play, to know the outside world, and given good mentoring from more mature people, especially closer parents and more time with the child to control every activity undertaken by the child. the child's desire to play depends on the motivation and encouragement of the parent to give permission and actively participate in educating the child. the role of adults, especially parents is needed. Parents' activeness of children can improve the growth and development of school-age children who are vulnerable to the environment. School-aged children should be provided with educative games that provide knowledge, feelings, and imitate good actions into qualified characters. 


\section{References}

[1] Andina, Elga. (2014). Budaya Kekerasan Antar Anak di Sekolah Dasar. Pusat Pengkajian, Pengolahan Data dan Informasi (P3DI), Sekretariat Jenderal DPR RI. (Online), http://berkas.dpr.go.id/pengkajian/files/i nfo_singkat/Info\%20Singkat-VI-9-IP3DI-Mei-2014-63.pdf, diakses pada tanggal 06 Juli 2017.

[2] Bronfenbrenner U. (1994). Ecological models of human development. In International Encyclopedia of Education, Vo. 3, 2nd, Ed. Oxford: Elveier.

[3] Dake, J. A., Price, J. H., dan Telljohann, S. K. (2003). The Nature and Extent of Bullying at School. The Journal of School Health, 73(5):173-180. (Online), http://media.proquest.com/media/pq/cla ssic/doc/348101681/...3D, diakses pada tanggal 06 Juli 2017.

[4] Hurlock, E. B. (1980). Psychology Child Development: An Approach Throughout Range Life (5th ed.) (Istiwidayanti, Soedjarwo, Trans.; Silabat, R, M, Eds.). Jakarta, Indonesia: Erlangga.

[5] Kohlberg L. dan Hersh R.H. (1977). Moral development: a review of the theory. Theory into Practice, Vol. 16, No. 2 , Moral Development. (Apr., 1977), pp.53-59.

[6] KPAI. (2014). Kasus Bullying dan Pendidikan Karakter. (Online), http://www.kpai.go.id/berita/kpaikasus-bullyingdan-pendidikankarakter/html, diakses pada tanggal 06 Juli 2017.

[7] Latifah, Fika. (2012). Hubungan Karakteristik Anak Usia Sekolah dengan Kejadian Bullying di Sekolah Dasar X di Bogor. Skripsi. Jakarta: Fakultas Ilmu Keperawatan Universitas Indonesia. (Online), http://lib.ui.ac.id/file?file=digital/20313 561-S43718-Hubungan\%20karakteristik.pdf, diakses pada tanggal 06 Juli 2017.

[8] Lickona T. (2001) What is good character? Journal Reclaiming Children and Youth; Winter 2001; 9, 4; ProQuest pg. 239.

[9] _ (2013). Pendidikan Karakter: Panduan Lengkap Mendidik Siswa Menjadi Pintar dan Baik. Bandung: Nusa Media.

[10] Megawangi, R. (2009). Menyemai Benih Karakter. Bogor: Indonesia Heritage Found-ation.

[11] Monks, F.J. et al. 1989. Psikologi Perkembangan Pengantar dalam Berbagai Bagiannya, Yogyakarta: Gajdah Mada University Press.

[12] Potter, P. A., dan Perry, A. G. (2005). Buku Ajar Fundamental Keperawatan: Konsep, Proses dan Praktik, Edisi 4, Vol. 1. Jakarta: EGC.

[13] Puspitawati dan Setioningsih S.S. (2012). Gender dan keluarga, konsep danrealita di indonesia. Bogor : IPB Press.

[14] Santrock J.W. (2012). Life span development, perkembangan masa hidup.Jakarta: Erlangga.

[15] Siswati dan Widayanti, C. G. (2009). Fenomena Bullying di Sekolah Dasar Negeri di Semarang: Sebuah Studi Deskriptif. Jurnal Psikologi UNDIP, 5(2). (Online), http://core.kmi.open.ac.uk/download/pd f/11710457.pdf, diakses pada tanggal 06 Juli 2017.

[16] Soedjatmiko, Nurhamzah, W., Maureen, A., dan Wiguna, T. (2011). Gambaran Bullying dan Hubungannya dengan Masalah Emosi dan Perilaku pada Anak Sekolah Dasar. Sari Pediatri, 15(3):174-180. (Online), http://saripediatri.idai.or.id/pdfile/15-3- 8.pdf, diakses pada tanggal 06 Juli 2017. 